\title{
URBAN VIOLENCE, PRISON CONDITIONS AND HUMAN DIGNITY
}

Ana Paula de Barcellos

This paper is about a situation that perhaps represents one of the most radical and profound challenges to the reality of the consensus that contemporaneous western societies - and Brazilian society in particular - claim they share regarding the equality and essential or ontological dignity of mankind. It is an attempt to investigate how Brazilian society, immersed in a context of fear as a result of urban violence, deals with its prison population. ${ }^{1}$ This paper is divided into three main parts. Part one deals with a situation of fact: traditional, ongoing, generalized, serious and practically institutionalized violation of the fundamental rights of prison inmates in Brazil. This situation of fact easily leads one to conclude that inmates in Brazil are not treated like human beings (and are probably not even considered human beings).

Part two is an attempt to examine some possible explanations of why this situation exists. The conclusions at this point are not very encouraging. The easy explanations do not fit together very well. The way Brazilian society treats inmates cannot be properly or fully explained by circumstantial causes or problems that can easily be resolved by typical legal mechanisms (adjudication, logic, etc.). The Brazilian prison system is complex and resistant to change due to ingrained social and cultural characteristics of the Brazilian people. In part three, the paper tries to suggest that there is a connection between how prisoners are treated and the current level of urban violence in Brazil as a contributing factor. Considering that neither the principle of human

\footnotetext{
${ }^{1}$ As has been repeated for many decades, it seems that one of the most revealing tests regarding the civility of a society is really how it treats prisoners and the helpless (the aged and those with special needs, among others).
} 
dignity nor the actions of the legal system have been able to change the scenario that has built up in recent decades, perhaps it would be useful - to start a forum of discussion of this topic - to suggest that inhumane treatment of inmates is not just a problem restricted to prisons: society as a whole receives the effects of this policy in the form of more violence

\section{$\underline{\text { I. Appalling prison conditions in Brazil }}$}

The Brazilian penal system has many serious problems. So many, in fact, that the President of the Brazilian Federal Supreme Court was quoted as saying at the 12th United Nations Congress on Crime Prevention and Criminal Justice held in Salvador, Brazil in April 2010 that Brazil's "prison system is on the brink of total collapse."2 All of these problems cannot be described here in a comprehensive way, but one in particular is worth highlighting. It is perhaps the most elementary of all - one that leads to various others: overcrowding. According to official data published in 2009, Brazil’s prisons have exceeded their capacity by (at least) 139 thousand inmates, for whom there is no physical space. ${ }^{3}$ Consequently, inmates are literally crammed into prison and jail cells. At several locations in Brazil, prisoners are kept standing in the corridors of police stations or confined in containers. This overcrowding makes it impossible to separate inmates by their age or the seriousness of their crimes. Brazil is experiencing

\footnotetext{
${ }^{2}$ Available online at: <www.conjur.com.br/2010-abr-15/deficiencia-sistema-carcerario-beira-falencia-total-peluso>. Accessed on April 18, 2010. Interesting enough, the comment the National Penitentiary Department Chief made about the Chief Justice of the Brazilian Supreme Court's statement was that this problem has existed for decades.

${ }^{3}$ This is official information (relative to year 2009) contained on the website of the National Department of Penitentiaries of the Ministry of Justice. Available at: <portal.mj.gov.br/depen/data/Pages/MJD574E9CEITEMIDC37B2AE94C6840068B1624D28407509CPTBRNN.ht $\mathrm{m}>$. Accessed on April 16, 2010.
} 
situations where women and men are kept together in the same cell. ${ }^{4}$ Below is some concrete data that will give the reader a better idea of how real this situation is.

From mid-2007 to mid-2008, a Congressional Investigating Committee (CPI) organized by the Chamber of Deputies investigated the Brazilian penal system, arriving at alarming conclusions that were widely publicized. ${ }^{5}$ According to December 2007 data, the Brazilian inmate population was estimated at 422,590. However, Brazil's prison capacity was only 275,194. The CPI report concluded that none of the existing prisons are in compliance with Brazilian legislation that has been in effect since 1984, requiring that each convict be lodged in an individual cell equipped with a bed, a toilet and a sink, with a minimum of $6 \mathrm{~m}^{2}$ of space each. The CPI reported that overcrowding is not a new problem: it has existed at least since the beginning of the 19th century. Specialized historians confirm that, in fact, overcrowding in the prison system is not a recent phenomenon. ${ }^{6}$

According to the CPI's report, besides overcrowding, other serious but routine problems were observed in several states of the Brazilian Federation. Prisoners often lacked access to what we would consider minimum amounts of water necessary for basic hygiene or consumption. Another problem is that cells were frequently contaminated by overflowing sewage lines and the permanent accumulation of garbage, including human feces. In addition, urine was often kept in soft-drink bottles in the corners of cells, since there are not enough sanitary facilities. The CPI

\footnotetext{
${ }^{4}$ In the year 2007 at least 5 cases were reported of woman who were kept in the same cell as men. At least one of them reported having been sexually abused (available at: <noticias.terra.com.br/brasil/interna/0,OI2099518EI5030,00.html>; accessed on April 16, 2010).

${ }^{5}$ The entire final report is available at <bd.camara.gov.br/bd/handle/bdcamara/2701>. Accessed on April 11, 2010.

${ }^{6}$ MAIA, Clarisssa Nunes, SÁ NETO, Flávio de, COSTA, Marcos, BRETAS, Marcos Luiz (org.), História das prisões no Brasil [ History of the Prisons in Brazil] (volumes I and II), 2009.
} 
report cited several examples in which there was only one toilet for more than 70 inmates in a single cell, whose flush mechanism did not work and in which water was poured just once a day for flushing purposes. The result, obviously, was a total lack of hygiene, intolerable odor and proliferation of various types of insects and vermin. These toilet stalls often had no doors and the inmates were forced to use them in full view of dozens of other inmates who occupied the same cell, that is, when the toilet was more than just a hole in the floor. Water for the prisoners to wash their hands after using the toilet was quite rare.

The CPI also described cases where, as a rule, there were no mattresses or not nearly enough, when they existed at all. The food was usually insufficient and of poor quality, when not spoiled. In many prisons the food was served in plastic bags and inmates had to eat it with their bare hands because eating utensils were not provided. Clothing was also not provided. Lack of these items (mattress, clothing, food, etc.) has led to the growth of a flourishing black market inside these establishments. Another problem observed was the lack of any means to control the temperature in the cells, which often rose to almost 50 degrees Celsius in the summer.

A document dated September 2007, prepared by the Ministry of Justice, part of the Federal Executive Branch, titled the "National Penitentiary Policy Plan,” stipulated as the first of its priorities for officials responsible for conducting and carrying out the penitentiary policy in Brazil the need to release funds for the construction and remodeling of prisons.7 In June 2008, the National Department of Penitentiaries, also part of the Federal Executive Branch, issued a publication identified as "Consolidated Data," containing information regarding the profile and

\footnotetext{
${ }^{7}$ V. <http://portal.mj.gov.br/cnpcp>.
} 
evolution of the Brazilian prison population from 2003 to 2007, in which overcrowding was evident.8

In spite of the work and conclusions of the CPI and the documents referred to above, produced within the Federal Executive Branch, the reality of Brazil's prison conditions does not appear to have changed significantly in recent years. According to information provided by the Office of Public Defenders of São Paulo - the richest and most developed state in Brazil - in 2008, 59 of the 64 public women's jails in São Paulo were operating greatly beyond their capacity. There were 4,057 female inmates in a system that could house only 1,687. In September 2008, a lower-court judge granted a request by the Office of Public Defenders to close down one of these units - a Public Women's Jail located in the municipality of São Bernardo do Campo, São Paulo. It held 193 inmates but only had a capacity for 32. It lacked mattresses and hygienic and medical supplies for the prisoners. At the public women's prison in Indaiatuba, also in the state of São Paulo, each single-size mattress was being shared by three inmates. Others were forced to sleep in the bathroom due to lack of space. Without any personal hygienic supplies, the prisoners had to use the insides of bread loaves as an absorbent.9

In February 2009, the overcrowding in the central prison of Porto Alegre, in the state of Rio Grande do Sul, was so bad that each inmate occupied an average of just $1.71 \mathrm{~m}^{2}$, with many

\footnotetext{
${ }^{8}$ Available online at:

<http://portal.mj.gov.br/cnpcp/data/Pages/MJD574E9CEITEMIDC37B2AE94C6840068B1624D28407509CPTBR NN.htm>. Accessed on: April 18, 2010.

${ }^{9}$ Available online at:

<www.defensoria.sp.gov.br/dpesp/Conteudos/Noticias/NoticiaMostra.aspx?idItem=3109\&idPagina=3260>, accessed on April 11, 2010. After several riots, the jail at Indaiatuba was officially deactivated in June 2009 and the inmates were transferred to other prisons in the state.
} 
cells averaging as little as $0.45 \mathrm{~m} 2$ per inmate. The prison held 4 thousand inmates more than its capacity.10 In the state of Espírito Santo, one cell with a capacity for 36 inmates housed 256 inmates, all of whom shared a single bathroom (data in May 2009). That same state also kept prisoners, in containers, including minors.11 One report told of 34 people housed in a container with no bars or windows who were not allowed out in the sunlight and fresh air. The states of Santa Catarina and Pará also kept prisoners in containers as a way of emptying out the local jails, which were so overcrowded with inmates.12 In the state of Paraíba (data from May 2009), the situation was critical at all the prison units. Just as an example, one prison with a capacity for 400 inmates was housing 1,100. The available bathrooms had no doors, the toilets were broken and the floor was wet from backed-up sewer lines.13

The news about the degrading situation of Brazil’s prison population has already had repercussions abroad and even mobilized intervention by international human rights organizations. In 2002 the Interamerican Court of Human Rights ordered Brazil to implement a series of measures to guarantee the life and physical integrity of the prisoners at one of the biggest prisons in the country’s northern region (Urso Branco Prison in Rondônia). Little has

\footnotetext{
${ }^{10}$ Available online at: <www.conjur.com.br/2009-fev-09/juiza-manda-estado-rs-criar-mil-vagas-presidios> (accessed on April 18, 2010). Faced with this situation, the court's decision called for the progressive creation of space for almost 4 thousand inmates in the state. The decision was appealed by the state of Rio Grande do Sul and, on April 22, 2010, a decision of the State Court of Appeals was still pending.

${ }^{11}$ Available online at:

$<$ http://ultimainstancia.uol.com.br/new_site/novonoticias/CNJ+PEDE+SOCORRO+MEDICO+A+PRESOS+EM+C ELA+HIPERLOTADA+NO+ES_63953.shtml>. Accessed on April 11,2010.

${ }^{12}$ Available online at:

$<$ http://ultimainstancia.uol.com.br/noticia/SUPERLOTACAO+CARCERARIA+FAZ+COM+QUE+ESTADOS+M ANTENHAM+PRESOS+EM+CONTEINERES_67177.shtml>. Accessed on April 11, 2010.

${ }^{13}$ Available online at:

$<$ http://ultimainstancia.uol.com.br/new_site/novonoticias/SITUACAO+DE+PRESIDIO+NA+PARAIBA+NAO+PO

DERIA+SER+PIOR+DIZ+PROCURADOR_64067.shtml>. Accessed on April 11, 2010.
} 
been done since then. The orders of the OAS Court were not complied with and in October 2009 Brazil was required to go before the Court once again to explain what was going on at that same prison.14 The conditions at the prisons in the state of Espírito Santo also resulted in Brazil being summoned by the UN to provide explanations in 2010. At a parallel session of the 13th Meeting of the UN's Council on Human Rights held in March 2010, Brazil's representatives had to respond to accusations received by that organization.15

There is no need to continue describing this spectacle of horrors, but some conclusions can be drawn at this point. Although it is a kind of truism, the first conclusion we can arrive at here is that the treatment given to inmates in Brazil, as described above, is a gross violation of human rights. I will get further into this point later on. The second conclusion is that the violation of prisoners' human rights in Brazil constitutes normal treatment (from a statistical standpoint) of that segment of the population. It seems correct to say that in any prison system anywhere in the world eventual violations of the rights of prisoners can always be observed. The difference is that in other parts of the world these violations are an exception, a deviation from the norm, to be punished by Law. Just as in any other area in which individuals can exercise their liberty, there will always be a certain percentage that deviates from the standard defined by Law. This is why the very existence of the Law is necessary. In Brazil, however, violation is not the exception: it is the rule. This is not a case of occasional or localized deviation, but of a general standard observed in Brazil as a whole. Adequate treatment is the exception. The third

\footnotetext{
${ }^{14}$ Available online at:

$<$ http://ultimainstancia.uol.com.br/noticia/BRASIL+SE+EXPLICA+A+CORTE+DA+OEA+POR+CAOS+EM+PR ESIDIO+DE+RONDONIA_66000.shtml>. Accessed on April 18, 2010.

${ }^{15}$ Available online at:

<www.diariosp.com.br/Noticias/DiaaDia/2164/ONU+questiona+Brasil+sobre+presidios+do+Espirito+Santo>. Accessed on April 18, 2010.
} 
conclusion is that this inhumane treatment of prisoners does not constitute anything new in the history of Brazil.

\section{Why?}

What explanations could there be for the picture I have just painted? Why has Brazil treated its prison population so cruelly and inhumanely for so long? Why did this picture not change, for example, after the return of democracy in the 1980s and, particularly, after the enactment of the Constitution of 1988? It is necessary to recognize that the theoretical effort to identify these explanations will require a comprehensive multi-disciplined investigation that is outside the scope of this paper. Nevertheless, although it is not feasible to demonstrate fundamentally what causes led directly to the picture described above, it is possible to identify some "non-explanations," that is: some causes one could even cogitate to explain the problem but which, in reality, are not relevant or whose relevance is significantly reduced. The usefulness of identifying non-explanations is to exclude them at the beginning of the debate (or at least demonstrate their lack of relevance to the debate) in order to facilitate our approximation to the causes that, in fact, are relevant. Some non-explanations will be enunciated and examined below and, at the end of this topic, a positive explanation for this phenomenon will also be considered.

1. The first possible explanation for the deplorable conditions in Brazil's penal system which is, strictly speaking, a non-explanation, as we will show - is the following. Brazil, for particular cultural reasons, perhaps does not share the international consensus regarding human rights in general, and of prison inmates in particular, resulting in the Brazilian penal system 
described above. It so happens that this statement clearly does not correspond to the reality of Brazilian manifestations regarding this subject. Besides supporting major international documents for the protection of human rights, such as the Universal Declaration of Human Rights, ${ }^{16}$ the Interamerican Convention on Human Rights ${ }^{17}$ and,${ }^{18}$ the International Pact on Civil and Political Rights ${ }^{19} 20$-, which already contain provisions regarding the rights of inmates -, Brazil has also endorsed international documents dealing specifically with the rights of suspects, convicts and prisoners. Some examples are the United Nations Convention against Torture and Other Forms of Cruel, Inhumane or Degrading Treatment or Punishment ${ }^{21}$ (and Additional Protocol ${ }^{22}$ ), the Interamerican Convention to Prevent and Punish Those Who Commit Torture, ${ }^{23}$ the Convention relative to the Treatment of Prisoners of $\mathrm{War},{ }^{24}$ the Minimum Rules for the

\footnotetext{
${ }^{16}$ Universal Declaration of Human Rights: "Article V. No one shall be subjected to torture or cruel, inhumane or degrading treatment or punishment."

${ }^{17}$ Decree no. 678/1992.

${ }^{18}$ ICHR: “Article 7 Right to personal liberty: 5. Any person detained or held must be taken without delay to the presence of a judge or other authority authorized by law to exercise judicial functions and has the right to be judged within a reasonable period of time or else be set free, without detriment to the prosecution of the case. His/her freedom can be conditioned to guarantees that assure his/her appearance in court. 6. Any person deprived of freedom has the right to seek recourse from an authorized judge or court, and for the latter to decide, without delay, the legality of his/her arrest or detention and order his/her release if his/her arrest or detention are deemed illegal. In the States whose laws stipulate that any person threatened with loss of his/her freedom has the right to seek recourse from an authorized judge or court to decide the legality of such threat, such recourse may not be restricted or abolished. The request for recourse may be filed directly by the person or by another person. 7 . No one may be detained for debts. This principle does not limit the orders of the authorized judicial authority issued by virtue of default of an obligation to provide food."

${ }^{19}$ Decree no. 592/92.

${ }^{20}$ International Pact on Civil and Political Rights: “Article 7 - No one may be subjected to torture or to cruel, inhumane or degrading treatment. Above all, it is forbidden to subject any person to medical or scientific experiments without that person's consent. Article 10 - 3. The penitentiary regimen shall consist of a treatment whose purpose is to morally reform and rehabilitate the prisoners. Juvenile delinquents shall be separated from the adults and receive treatment appropriate to their age and legal condition.”

${ }^{21}$ Decree no. 40/1991.

${ }^{22}$ Decree no. 6.085/2007.

${ }^{23}$ Decree no. 98.386/1989.

${ }^{24}$ Decree no. 22.435/1933.
} 
Treatment of Prisoners ${ }^{25}$ and the Tokyo Rules - minimum rules of the United Nations for the preparation of non-private measures of liberty. ${ }^{26}$ Thus, to attribute the degradation of the Brazilian penal system to an alleged cultural trait of the country, saying that it has a different view of human rights, would simply not be a true explanation of the problem.

2. A second possible explanation - also, in reality, a non-explanation - involves the fragility of Brazilian Law in relation to this topic. As we all know, it is not uncommon for countries to commit themselves to certain policies on the international stage, but with no intention of implementing them domestically. Thus, it would be possible to cogitate the following explanation for the appalling conditions of Brazil's penal system: in spite of Brazil's international commitment to human rights in general and to the rights of prison inmates in particular, Brazil's domestic legislation does not reflect this concern. But it just so happens that this explanation also fails to correspond to the reality of internal Brazilian law. The Brazilian Constitution of 1988 guarantees prison inmates a series of specific rights, in addition to the traditional rights of due process of law. The Constitution expressly stipulates, for example, the prison inmates' right to physical and moral integrity, the right to serve their prison sentence in different establishments depending on the nature of their crime, their age and gender and the right of female inmates to be with their children during the breast-feeding phase. The

\footnotetext{
${ }^{25}$ Incorporated in Brazil by Resolution no. 14/1994 of the National Council of Criminal and Penal Policy (CNPCP), which establishes the minimum rules for the treatment of inmates in Brazil. Their text is not identical.

${ }^{26}$ Successive revisions to the Penal Code and Law of Alternative Penalties (Law no. 9.714, of November 25, 1998, which also altered the Penal Code) incorporated some guidance to the Rules.
} 
de Barcellos

Constitution forbids cruel punishment and establishes the dignity of man and woman as a principle of the Republic. ${ }^{27}$

Even before the Constitution of 1988, a law had been enacted that describes in great detail the rights of inmates in the context of their incarceration: Law no. 7.210, of July 11, 1984 - the Law of Penal Execution. And ten years later, in 1994, Supplemental Law no. 79 was enacted, creating the National Penitentiary Fund (FUNPEN) and listing the resources that ought to be directed to it. FUNPEN's resources should be used to build, remodel, expand and improve penal establishments, as well as for other activities necessary to modernize and improve Brazilian penitentiaries. ${ }^{28}$ Among the rights of prisoners included in Law no. $7.201 / 84$ were the right to be housed in an individual cell with a minimum of $6 \mathrm{~m}^{2}$ of area, equipped with a bed, a toilet and a sink and some means to control air flow and temperature, the right to receive food and clothing and have access to hygienic installations, the right to receive medical treatment, including medical, dental and pharmaceutical service, the right to educational instruction and the right to legal assistance if unable to afford an attorney, among other things. ${ }^{29}$ With regard to legal

\footnotetext{
${ }^{27}$ The Brazilian Constitution of 1988: "Article 1, III - establishes the principle of the dignity of man as a fundamental [principle] of the Federative Republic of Brazil; (...) Article 5 (...) XLVII - there will be no penalty: (a) of death, except in the case of declared war, according to the terms of article 84, XIX; (b) of a perpetual nature; (c) of forced labor; (d) of banishment; (e) of a cruel nature; XLVIII - the sentence shall be served in different establishments, according to the nature of the crime, the age and gender of the convict; XLIX - prisoners are assured that their physical and moral integrity will be respected; $\mathrm{L}$ - female prisoners shall be assured conditions that allow them to remain with their children during the breastfeeding period."
}

${ }^{28}$ Supplemental Law no. 79/94: "Article 1 This law hereby institutes within the Ministry of Justice, the National Penitentiary Fund (FUNPEN), to be governed by the Department of Penitentiary Matters of the Office of the Secretary of Rights, Citizenship and Justice, with the purpose of providing funds and the means for financing and supporting the activities and programs for the modernization and improvement of the Brazilian Penitentiary System. (...) Article 3 The FUNPEN funds will be applied in: I - constructing, remodeling, expanding and improving penal establishments."

${ }^{29}$ Law no. 7.210/84: "Article 10. The State has the duty to provide assistance to prisoners and interned persons aimed at preventing crime and guiding their return to life in society. Sole paragraph. The assistance shall extend to their release. Article 11. Assistance shall be: I - material; II - medical; III - legal; IV - educational; V - social; VI religious. Article 12. Material assistance to prisoners and inmates shall consist of the supply of food, clothing and hygienic installations. (...) Article 14. Healthcare assistance to prisoners and interned persons of a preventive and 
assistance and with the purpose of expanding access thereto by those who cannot afford it, the Constitution of 1988 called for the creation of the Office of Public Defenders to serve those in need of legal service, who are also able to file judicial actions free of charge (article 5, LXXIV and article 134). The Constitution also attributed to the Public Prosecutor [Ministério Público] the duty to defend class and diffused interests (article 129).

The conclusion here is also that it is not possible to explain the picture of disrespect of the rights of inmates based on the argument that Brazilian Law is fragile or remiss in regard to this subject. On the contrary, although inmates probably constitute the group least capable of participating in a public debate regarding their rights, Brazilian legislation is considered one of the most progressive in the world. We cannot blame the Law.

3. A third explanation to explain the overcrowded Brazilian prison system would be that this is a very recent and unexpected problem and that, for this reason, the public authorities were unprepared. Everything was fine until, suddenly, something unexpected triggered enormous overcrowding in the prisons and there was not enough time for the public policies that were adopted to produce the desired effects of minimizing the problem. This explanation is also unreal but deserves specific attention. It is true that the prison population grew 37\% between 2003 and 2007, whereas the Brazilian population grew little more than 5\% in the same period. So there

curative nature shall include medical, pharmaceutical and dental care. Article 15. Legal assistance is intended for prisoners and interned persons who do not have the financial resources necessary to hire an attorney. (...) Article 17. Educational assistance will include providing the prisoner and interned person with scholastic instruction and professional training. (...) Article 22. The purpose of social assistance is to help prisoners and interned persons prepare for their return to liberty. (...) Article 88. Convicts shall be housed in individual cells that will contain a bed, a toilet and a sink. Sole paragraph. The following are basic cell requirements: a) healthy environment in terms of air circulation, protection from the sun, and adequate temperature control for human existence; b) a minimum of $6.0 \mathrm{~m} 2$ (six square meters).” 
was a relevant increase in the prison population in recent years. It is also true that many temporary arrests were made in Brazil (namely: persons arrested but not officially sentenced) that contributed to the system's overcrowded conditions. ${ }^{30}$

Nevertheless, although one cannot ignore the impact of the recent increase in prison inmates on the problem of overcrowded prisons, it would not be correct to conclude that this phenomenon observed above all from 2003 to 2007, is the explanation for the chaos that exists in the Brazilian penal system. First of all, the overcrowding of Brazilian prisons did not suddenly begin in 2003. The problem goes way back to the 19th Century and continuously worsened throughout the 20th century. The Brazilian authorities responsible for penitentiary policy recognize that the overcrowding situation has been very serious for at least the past 40 years, ${ }^{31}$ with specific legislation having been enacted more than 25 years ago to establish standard prison condition requirements that, so far, have not been met by practically any of Brazil’s prisons.

On the other hand, strictly speaking there was nothing unpredictable about the progressive and relevant increase in the Brazilian prison population. Although there are no precise statistics in Brazil in this regard, it is estimated that there could be as many as 300 thousand outstanding arrest warrants. ${ }^{32}$ Data gathered in the state of Rio de Janeiro reveals that in

\footnotetext{
${ }^{30}$ One of the recent initiatives of the National Council of Justice in the attempt to minimize overcrowding is the performance of free work (mutirões) to examine the situation of temporary prisoners and release those held illegally (<www.cnj.jus.br $>$ ).

${ }^{31}$ Available online at: < www.conjur.com.br/2010-abr-15/deficiencia-sistema-carcerario-beira-falencia-totalpeluso>. Accessed on April 18, 2010.

${ }^{32}$ Available online at: <www.conjur.com.br/2010-fev-27/ninguem-sabe-quantos-sao-mandados-prisao-naocumpridos-brasil $>$. Accessed on April 20, 2010. As long these same lines, see the Report of the Institute for Human Rights of the International Bar Association (Um em cada cinco: a crise nas prisões e no sistema de justiça criminal brasileiro) [One in every five: the crisis in the Brazilian prisons and criminal justice system], of February 2010, p. 18: "The Ministry of Justice estimated that in 1994 there were 275,000 outstanding arrest warrants significantly
} 
2002 only $2 \%$ of all reported ${ }^{33}$ homicides in the state resulted in arrest and conviction and, considering the period 2002 to 2004, that number did not exceed $10 \% \cdot{ }^{34}$ In other words: in spite of the growth in the prison population observed since 2003, the level of overcrowding did not worsen only because the Brazilian criminal justice system's operates precariously, to say the least. And, considering that improvement in criminal investigation will have to be a permanent goal of the public authorities, it is certain that any level of improvement would aggravate the problem of overcrowding in the prison system. In short: it would be wrong to attribute the problem of overcrowded prisons to an increase in the number of arrests in the period 2003 to 2007.

4. A fourth explanation one could imagine for why Brazil's overcrowded prison problem cannot be solved is the following: Brazil is a very poor country or Brazil has suffered a major catastrophe recently and does not have the resources to invest in this area, either because there simply are not resources or because of other emergencies that have priority. Fortunately, none of these explanations is factual. Brazil is not an impoverished country. Nor has it suffered any recent catastrophes. In other areas, important - and costly - public policies have been

more than the number of individuals incarcerated. In Brasília alone, the Public Prosecutor announced in this report that of the 15,077 arrest warrants issued in its jurisdiction over the past three years, only one third were effectively carried out; the suspects in the remainder of the cases are effectively at large. (...) it is difficult to obtain updated, precise figures about this issue, but the most commonly cited number of outstanding arrest warrants is 300,000. Based on the same calculation that every five cases represents only one person, this means that there are approximately 60,000 persons convicted to prison sentences that were not served" (available online at: $<$ http://www.ibanet.org/>, accessed on April 22, 2010).

${ }^{33}$ Another problem is that only a small fraction of crimes are reported. See THOMPSOM, Augusto. Quem são os criminosos - o crime e o criminoso: agentes políticos [Who are the criminals - the crime and the criminal: political agents], 2007.

${ }^{34}$ Merely for comparison purposes, according to the United Nations, the average number of homicides solved in North American and European countries is 49\%. These figures come from the National Concourse of Applied Public Safety Research, supported by the Ministry of Justice. Available online at: http://www.ucamcesec.com.br/arquivos/atividades/mensur_impun_sist_ignacio.pdf >. Accessed on April 22, 2010. 
implemented, unopposed by arguments alleging lack of resources, for example, free medicine ${ }^{35}$ and free access to higher education at private institutions paid for by the State. ${ }^{36}$ The debate involving the establishment of priorities for the allocation of public resources will always be relevant when discussing not only investments in the prison system, but also any kind of public spending, insofar as demands are unlimited but public resources are not. This obvious fact merely means that money will always be an issue for any public policy, but cannot be described as the cause of the chaos in the Brazilian penal system.

There is also some specific data to reveal that the generic argument of lack of money is far from being an adequate explanation for the problem of overcrowding in Brazilian prisons. As already mentioned above, in 1994 the Lawmakers created a specific fund fed by permanent sources of revenue to pay for the penitentiary policies. At the same time, the press reported at the end of 2009 that funds earmarked for implementation of public policy in that area have been sitting unused for years for various reasons. ${ }^{37}$ One of these reasons is that the municipalities refuse to allow the construction of new prisons within their borders. So, here again we cannot point to lack of resources as the central cause of the problem of overcrowding prisons in Brazil.

\footnotetext{
${ }^{35}$ See for example, the legal determination that obliges the Sistema Único de Saúde [Single Health System] to distribute free medicine to HIV-positive patients - Law no. 9.313/96: "Article 1 Carriers of HIV (human immunedeficiency virus) and AIDS patients (Acquired Immune-Deficiency Syndrome) shall receive free of charge from the Sistema Único de Saúde all the medicine necessary for their treatment.”

${ }^{36}$ The Federal Government's University-for-All Program (PROUNI) was created by Law no. 11.096/95 and has the purpose of granting full and partial scholarships to attend private institutions of higher education to students who demonstrate a lack of funds to pay for their own studies and have no higher education diploma. Information available online at: <http://siteprouni.mec.gov.br/index.html >. Accessed on April 22,2010.

${ }^{37}$ Available online at:

<www.prro.mpf.gov.br/clipping/bc1047d17922921c878572dc7884923f.pdf > and <oglobo.globo.com/pais/mat/2009/10/31/recursos-para-presidios-estao-embargados-por-problemas-na-licitacao-deengenharia-ambientais-914497481.asp>. Accessed on April 22, 2010.
} 
5. Finally, a fifth reason one could imagine as an explanation for the Brazilian prison situation is ignorance: for some reason, the authorities and society are not aware of what goes on inside these prisons and the human rights violations that occur there. Since they are unaware of the facts, nothing can be done to end these violations. As already shown, this explanation is far from reality. As mentioned above, the public authorities themselves have made a relevant diagnosis of the problem and the press has widely publicized their findings to the public, especially the overcrowding. Therefore, it is impossible to argue that general unawareness is responsible for perpetuating the problems in the Brazilian prison system. There is no need to go forward with any argumentation based on this point.

It is possible to extract a conclusion from what has been set forth above. The question initially posed - why has Brazil treated its prison population so inhumanely and cruelly for so long? - cannot be answered in a consistent manner by any of the explanations considered above. Strictly speaking, concerns about human rights are present in Brazil (theoretically, at least); there is ample and detailed internal legislation about the rights of prison inmates and there is information about the disrespect that exists for that legislation. The problem of overcrowded prisons is not recent. There are even resources to counter it. But the situation persists with no significant changes and without any relevant approximation of reality to what rhetoric and the Law suggest.

If these answers are not relevant to an understanding of the problems or their relevance is limited, then how can they be explained? Why has Brazilian society coexisted passively for so many decades with the violation of prisoners' fundamental rights and with the repeated violation 
of pertinent legislation? Why has not the specific legislation referred to above "caught on?” Why is there such indifference on the part of society and the authorities, even though the legislation referred to above was approved by the same National Congress that has the authority to oversee the actions of the Executive Branch and the investment of public resources? Why does the population mobilize so easily to help victims of calamities both in Brazil and abroad but tolerates the situation of its own prisons, even though it is aware of the inmates' deplorable conditions? As already mentioned above, the construction of consistent answers to these questions requires complex, multi-disciplined investigations. Therefore, all this paper intends to do at the end of this topic is to suggest a possible explanation to reflect on.

A summary description has already been given above of how Brazil has explained its commitment to human rights in general and to the rights of prison inmates in particular by endorsing international conventions dealing with the subject and the by enacting internal laws. However, in spite of beautiful discourse and legislation, it seems that the formation of Brazilian culture has not yet been capable of incorporating the notions of the equality of individuals and the essential dignity of each human being. Thus, the formal commitments to human rights end up being constructed on a moral and philosophical foundation that is not really shared by the majority of society and, for that reason, when confronted by any threats - such as, for example, the threat of urban violence -, reveals its fragility.

The hypothesis raised here is that most of Brazilian society looks upon the concept of human dignity as being more linked to what the individual has or does than to the mere circumstance of being a human being. The dignity, therefore, is not something inherent to every 
human being, but rather, something circumstantial and tied to individual behavior. This would somewhat explain the permanent chaos that exists in the Brazilian penal system, in spite of all the formal legal structure described above. That non-ontological concept of human dignity can be described in the following terms: the prisoner committed (or is being accused of committing) crimes, so because of his/her reproachable conduct, the prisoner does not possess human dignity and, therefore, really has no right to be treated with dignity. Society can even improve the conditions in the penal system, and some efforts to do so can even be worthy of praise, but of course only after other social needs - tied to individuals who are endowed with human dignity are met. In other words: the rights of prison inmates are not really rights per se and the debate about them is confined to the space of benevolence. In a context of generalized fear due to the alarming levels of urban violence, benevolence simply does not find an adequate opportunity to flourish. ${ }^{38}$ Worse, fear brings out the fragility of the moral and philosophical conventions that form the basis of Brazilian society regarding the equality and dignity of individuals. Concrete acts or neglect by the public authorities, especially elected officials, seem to be molded to this concept held by the majority in Brazilian society.

It is interesting to note that the logic of this explanatory hypothesis seems to get very close to the underlying reasons for the debate initiated in various parts of the world, especially after the terrorist attacks of September, 11, 2001, regarding the flexibilization of the rights of individuals accused of terrorism. In effect, the discussion, for example, of the enemy's penal rights, presupposes precisely that the conditions of the holder of human rights (in the entire

\footnotetext{
${ }^{38}$ According to worldwide research conducted in 2003 by Instituto Vera de Justiça, Brazil is the country where more people express their fear of going out for a walk at night than in any other country (followed by South Africa, Bolívia, Botsuana, Zimbabwe and Colombia). Information gathered in the Report of the Institute of Human Rights of the International Bar Association (One in every five: the crisis in the Brazilian prisons and criminal justice system), of February 2010, p. 37 (available online at: <http://www.ibanet.org/>; accessed on: April 22, 2010).
} 
extent thereof), of human dignity and even the condition of being a human being are not irremediably associated to human beings for the simple fact that they are human beings. The individual does not have rights but rights are attributed by the community: certain crimes can lead to the individual's exclusion from the "community of rights" and generate his/her loss of the condition of being a person and a bearer of dignity and rights. Therefore, dignity is also not inherent to the human being but rather circumstantial and variable, depending on the way he/she behaves in society. ${ }^{39}$

It is also impressive, from a philosophical standpoint, that once again in the history of mankind a debate is being waged around whether or not human dignity is inherent to all individuals, a debate that cogitates the flexibilization of rights for a given category of criminals and that works toward manipulating the concept of human being. The risk that this kind of theoretical interpretation represents to the protection of human rights throughout the world is quite obvious and needs no further consideration. The gravity of the situation in Brazil, however, is derived from some peculiarities that should be noted. In the case of Brazil, there is no theoretical debate intended to flexibilize an already existing and reasonably consolidated model of human rights guarantees, as is the case, for example, surrounding the penal rights of the enemy in Germany. Brazilian reality has not yet even constructed or consolidated a model of human rights guarantees. Furthermore, in Brazil the logic that identifies the criminal as an enemy, someone without rights and even a non-person - not explicitly or on the theoretical level

\footnotetext{
${ }^{39}$ For some material about this discussion, see JAKOBS, Günther and CANCIO MELIÁ, Manuel, Direito Penal do Inimigo - Noções e Críticas [The enemy's penal rights: notions and critics], 2007; ZAFFARONI, Eugenio Raúl, $O$ Inimigo no Direito Penal [The enemy in Criminal Law], 2007; PREGER, Guilherme, Homo sacer da baixada [The slums' homo sacer], 2006; and CARVALHO, Thiago Fabres de, $O$ 'direito penal do inimigo' e o 'direito penal do homo sacer da baixada': exclusão e vitimização no campo penal brasileiro [The enemy's penal rights and the Criminal Law for the slums' homo sacer: exclusion and victimization in Brazilian Criminal Justice System], 2008.
} 
- ends up being applied in the context of any criminal activity and not, as the theoretical defenders of the enemy's penal rights intend, to individuals involved in crimes of a specific degree of gravity.

In summary, the explanations imagined at the beginning of this topic do not adequately or consistently explain how Brazilian society treats its prison population. The explanatory hypothesis imagined for this phenomenon involves the moral and social formation of Brazilian society, which, in spite of the discourse and the wording of laws, did not incorporate the notions of the equality and essential dignity of individuals, working differently with a concept of dignity tied not to the human being but to what the human being does or does not do.

III. Violation of the rights of inmates: more violence. An attempt to shift the discussion to another perspective

If the explanatory hypothesis proposed in the preceding topic can in fact be confirmed, Brazilian Law will confront (or continue to confront) a structural problem of greater gravity, since the capacity of the law to modify people's moral and philosophical concepts is quite limited, even more so in an environment of fear in which people feel permanently threatened by violence, which takes on the face and appearance of prison inmates. Thus, without detriment to the role the Law can play in this context, it seems relevant to bring up - also to encourage some debate in regard thereto - society's mistaken belief that the way it treats its prisoners will not have any negative repercussions on society itself, as if it were possible to rigidly separate these two worlds: the world outside from the world inside prison walls. 
Urban violence is a complex and multi-causal phenomenon. The purpose of this paper is not to discourse on its causes or the importance of each cause. What this paper intends to do is merely to note the following: that there are consistent indications that the inhumane treatment of prisoners in the Brazilian penal system ends up directly increasing the levels of urban crime and violence in at least two different ways: the large number of additional serious crimes committed by suspects in an attempt to avoid going to jail and the acutely high number of repeat offenders noted in Brazil.

In effect, suspects in Brazil frequently try at all costs to avoid prison by committing new and often much more violent crimes than the ones that led to their initial incarceration. Thus, it is common for suspects to resist arrest or even the mere approach of the police, shooting at them, stealing vehicles to flee from them and taking hostages. Unfortunately, it is very common for police chases to result in the death of the suspects themselves, the police and, especially, bystanders who unfortunately find themselves in the wrong place at the wrong time and end up getting caught in crossfire. ${ }^{40}$

One of the more plausible explanations for the spread of this kind of behavior in Brazil is precisely the hatred suspects have of the conditions they are subjected to prison: overcrowding,

\footnotetext{
${ }^{40}$ Unfortunately, many deaths occur in the context of police pursuits and these are repeated continuously. Below are some examples (all accessed online on April 23, 2010): <g1.globo.com/rio-de-janeiro/noticia/2010/04/perseguicaopolicial-faz-4-mortos-e-2-feridos-em-bonsucesso.html>; <www.tribunadonorte.com.br/noticia/perseguicao-acabaem-tres-mortos/138364>; <noticias.r7.com/rio-e-cidades/noticias/dois-homens-sao-mortos-durante-perseguicao-norecreio-dos-bandeirantes-zona-oeste-do-rio-20100111.html>; $<$ noticias.terra.com.br/brasil/noticias/0,,OI4270124-EI5030,00-

Tres+sao+mortos+em+perseguicao+apos+assalto+a+banco+no+RS.html>; and online.com.br/editoria/policia/news/437692/?noticia=PERSEGUICAO+POLICIAL+TERMINA+COM+DOIS+BA NDIDOS+MORTOS+EM+CURITIBA.
} 
de Barcellos

hunger, bad treatment, violence, torture and various sexual abuses. ${ }^{41}$ The perspective produced by this picture causes the suspect to prefer avoiding arrest at any cost, even through more acts of violence and crime. This is also because, in spite of the possibility that the sentences for these new crimes - if applied - might be longer than those associated with earlier crimes, as already mentioned, the percentage of convictions is still very small when compared with the number of crimes committed. Thus the threat of future conviction is much less important than the present threat of arrest and the hatred of conditions in the Brazilian prison system.

A second environment in which one observes a significant causal relationship between prison conditions and the increase in urban violence is the high number of repeat offenders. It is estimated that, after being released, $70 \%$ to $85 \%$ of Brazil's inmates go back to prison for new crimes. ${ }^{42}$ Even in Brazil, ${ }^{43}$ these percentages are relatively smaller in cases in which the

\footnotetext{
${ }^{41}$ Overcrowding is not the only problem in the Brazilian prison system, nor is it an isolated one. Regarding the topic of violence in the prisons, see the comments contained in the UN Special Report on Summary or Arbitrary ExtraJudicial Executions: "Delays in the processing of transfers, violent acts by prison guards and poor conditions in general lead to the growth of factions inside the prisons that succeed in justifying their existence to the inmate population as a whole by saying that they act in defense of the inmates to obtain benefits and avoid violence. Poor administration and prison conditions not only facilitate the occurrence of rebellions but also contribute directly to the growth of criminal factions.
}

At most units, the State fails to exercise sufficient control over the inmates and allows the factions (or other prisoners in the "neutral" units) to resolve issues of the units' internal security among themselves. Selected inmates sometimes receive more power over their fellow inmates than the guards themselves. They assume control (often brutal) over internal discipline and the distribution of food, medicine and hygiene kits. These practices often result in faction leaders taking control of the prisons." (available online at:

<http://www.iddh.org.br/v2//upload/09a88d3af9dd4328f461373078be620f.pdf>; accessed on: April 22, 2010). See also the Report of the Institute of Human Rights of the International Bar Association (One in every five: the crisis in the Brazilian prisons and criminal justice system), of February 2010 , p. 13: "The effective domination of many Brazilian prisons by criminal groups underscores the dramatic failure of the criminal justice and penal system's administration.” (available online at: <http://www.ibanet.org/>, accessed on April 22, 2010).

${ }^{42}$ Information available online at:

<http://portal.mj.gov.br/data/Pages/MJ47E6462CITEMID38622B1FFD6142648AD402215F6598F2PTBRNN.htm> , accessed on April 26, 2010.

${ }^{43}$ It is not easy to make adequate comparison between data from different countries, not only because the criteria used can vary a lot but also because criminal justice systems work in a quite different rhythm. Anyway, some information about what happens in other countries can be useful. In India, according to the National Crime Records Bureau, 8,7\% of the inmates go back to prison for new crimes (available online at: http://ncrb.nic.in/cii2006/cii- 
legislation allows and, in fact, applies alternate sentences that do not involve incarceration. ${ }^{44}$ The reasons for that causal connection are varied and may differ in nature: the inmate considered potentially less dangerous ends up being recruited into criminal factions inside the prison in order to survive the reality of prison life and then returns to crime when released; the inmate becomes completely brutalized by the inhumane treatment he/she receives and loses any perspective of a life outside of crime; the inmate receives no professional training or guidance so he/she can earn a living through work after being released, etc. ${ }^{45}$ Nevertheless, what one observes is that the probability of the individual committing new crimes after doing time in a Brazilian prison is quite high.

\section{Conclusions}

The main ideas set forth throughout this paper can be summarized in the following terms. For several decades the treatment of the prison population in Brazil has been, as a general rule not the exception - degrading and inhumane. This is true, in spite of Brazil's tradition on the international stage of rhetoric favoring human rights and prisoners’ rights in particular, its record

2006/CHAP11.pdf, accessed on April 26, 2010). Statistics Norway informs that, from 2001 to 2005, 47,1\% of the released from prison committed another crime in the country (available online at:

<http://www.ssb.no/english/subjects/03/05/a_krim_tab_en/tab/tab-2007-08-13-21-en.html>, accessed on April 26, 2010). The information provided by Swedish National Council for Crime Prevention is that, for 1991-2003, the number of repeat offenders varied from $23 \%$ to $36 \%$, depending on the criteria adopted (available online at http://www.bra.se/extra/pod/?action=pod_show\&id=19\&module_instance=11, accessed on April 25, 2010). In 1994, considering 15 American States, 67\% of the inmates committed another crime at some point of the three years after release from prison (available online at: http://bjs.ojp.usdoj.gov/content/pub/press/rpr94pr.cfm, accessed on April 26, 2010).

${ }^{44}<$ http://www.jus2.uol.com.br/DOUTRINA/texto.asp?id=11001>; and $<$ ultimainstancia.uol.com.br/noticia/ESTUDO+MOSTRA+QUE+CONDENADOS+A+PENAS+ALTERNATIVAS +TEM+BAIXA+REINCIDENCIA_68505.shtml>, accessed on April 23, 2010.

${ }^{45}$ It is also possible to imagine other reasons not directly related to the same explanatory hypothesis that, according to the above proposal, explain the perpetuation of these conditions. Once released, the ex-convict is largely shunned by society and this makes his/her integration difficult. 
of ample, detailed internal legislation regarding the rights of prisoners and the creation of funds reserved for prison reform. The explanation imagined for this situation of fact has to do with the cultural formation of Brazilian society, which has failed to incorporate notions of the equality and essential dignity of individuals, in spite of that rhetoric and legislation, working differently with a concept of dignity tied not to the human being but to what the human being does or does not do. Therefore, prison inmates are not considered worthy of dignity or human rights.

Finally, since the argument of human dignity has not produced its desired effects on the Brazilian reality and the laws already on the books have not been able to change prison conditions in recent decades, maybe it would be useful, in order to encourage more debate on the subject, to raise the perception that what society fears most - violence - might grow due to the way inmates are treated by the penal system. Two examples of this relationship between prison conditions and increased violence are the high number of repeat offenders and the new crimes frequently committed by suspects in their attempt to avoid arrest. 